\title{
Influence of reactive oxygen species on secretory component in the intestinal epithelium during hyperoxia
}

\author{
MIN ZHAO, SHIMIAO TANG, JUNCHI XIN and DONGYAN LIU \\ Medical Research Center, Shengjing Hospital, China Medical University, Shenyang, Liaoning 110000, P.R. China
}

Received October 5, 2016; Accepted May 19, 2017

DOI: $10.3892 /$ etm.2017.5027

\begin{abstract}
Redox imbalance is established in various human diseases. Treatment of intestinal epithelial cells with hyperoxia for a prolonged period of time may cause serious effects on redox balance. Secretory component (SC) protein is secreted by intestinal epithelial cells, and has a vital role in mucosal immune systems and intestinal defense. The present study aimed to investigate the influence of reactive oxygen species (ROS) on intestinal epithelial cells and intestinal epithelial $\mathrm{SC}$ protein under hyperoxic conditions. Caco-2 cells were treated with increasing concentrations of hydrogen peroxide $\left(\mathrm{H}_{2} \mathrm{O}_{2}\right)$ or $85 \% \mathrm{O}_{2}$ (hyperoxia) for $24 \mathrm{~h}$. Flow cytometry, immunohistochemistry staining, western blot analysis and reverse transcription-quantitative polymerase chain reaction were performed to detect the expression levels of SC protein. Significantly increased apoptosis and mortality rates were observed in hyperoxia- and $\mathrm{H}_{2} \mathrm{O}_{2}$-treated Caco-2 cells, as compared with the untreated control cells $(\mathrm{P}<0.05)$. Protein and mRNA expression levels of SC were significantly increased in hyperoxia- and $\mathrm{H}_{2} \mathrm{O}_{2}$-treated groups, as compared with the control group $(\mathrm{P}<0.05)$. During hyperoxia, intestinal epithelial cells were destroyed and ROS levels increased. Therefore, the results of the present study suggested that ROS might have an important role in intestinal injury in hyperoxic environments.
\end{abstract}

\section{Introduction}

Hyperoxic treatment (hyperoxia) is an indispensable therapeutic measure in some neonatal critical care conditions.

\footnotetext{
Correspondence to: Professor Dongyan Liu, Medical Research Center, Shengjing Hospital, China Medical University, 36 Sanhao Street, Shenyang, Liaoning 110000, P.R. China

E-mail: liudy19701010@sina.com
}

Abbreviations: ROS, reactive oxygen species; $\mathrm{H}_{2} \mathrm{O}_{2}$, hydrogen peroxide; IgA, immunoglobulin A; SC, secretory component; SIgA, secretory immunoglobulin $\mathrm{A}$; $\mathrm{pIgR}$, polymeric immunoglobulin receptor

Key words: hydrogen peroxide, hyperoxia, secretory component, reactive oxygen species, intestinal epithelial cell
For instance, supplemental oxygen used to treat infants born prematurely disrupts angiogenesis (1). An appropriate level of hyperoxia can induce an antioxidant response (2). However, hyperoxia over a prolonged period of time may have a serious toxic effect on bodily organs. A previous study indicated that the extensive clinical use of hyperoxia is hindered by potential organ injury that may arise by increasing the production of reactive oxygen species (ROS) (3). ROS are derivatives of cellular metabolic reactions that modulate the fundamental physiological functions of aerobic life (4). ROS, which may be produced in the mitochondria, have traditionally been regarded as by-products of aerobic metabolism, and primarily include oxygen ions and hydrogen peroxide $\left(\mathrm{H}_{2} \mathrm{O}_{2}\right)(5,6)$. ROS has been demonstrated to affect cell viability, proliferation, differentiation, aging, apoptosis and various other physiological and pathological processes (5). Mitochondrial ROS are critical for the functional stimulation of inflammation (7). At low levels, ROS may act as signaling molecules within cells (8). Under normal conditions, the generation and removal of ROS are in dynamic balance in vivo and are beneficial to the organism. Furthermore, previous results have indicated that ROS have a critical function upstream and downstream of nuclear factor $(\mathrm{NF}-\kappa \mathrm{B})$ and tumor necrosis factor pathways (9). However, excessive generation of ROS is harmful, with the hydroxyl radical considered the most harmful (9). In particular, $\mathrm{H}_{2} \mathrm{O}_{2}$ may significantly reduce the activity of superoxide dismutase, glutathione peroxidase, catalase and lipase (10). Furthermore, $\mathrm{H}_{2} \mathrm{O}_{2}$ affects numerous intracellular signaling pathways such as mitogen-activated protein kinase (MAPK) and c-Jun $\mathrm{N}$-terminal kinase, modify the activity of key signaling proteins including catalase, glutathione peroxidase and peroxiredoxin and promotes tyrosine phosphorylation by activating protein tyrosine kinases (11). These activities demonstrate that hyperoxia may inhibit cell proliferation and stimulate cell mortality (12).

Immunoglobulin A $(\operatorname{Ig} \mathrm{A})$ is the first line of defense in mucosal immunology (13). Secretory immunoglobulin A (SIgA) is composed of $\operatorname{IgA}$, secretory component (SC) protein and $\mathrm{J}$ chain protein (14). SC is the extracellular component of the polymeric immunoglobulin receptor $(\mathrm{pIgR})$, which is located on the basolateral surface of mucosal epithelial cells $(15,16)$. pIgR has been identified as the precursor of SC protein (17) and the membrane SC has been termed pIgR (15). pIgR transports IgA antibodies across intestinal epithelial cells (18), and has acritical role in mucosal immune systems 
and intestinal defense $(13,19)$. SC participates in innate protection against mucosal pathogens (20) and protects SIgA from proteolytic degradation (21).

Long-term hyperoxic treatment may have serious toxic effects on intestinal epithelial cells, in vitro and in vivo (22-25). Our previous results demonstrated that SIgA and SC were markedly increased in neonatal rats under hyperoxic conditions (25). SC has also been demonstrated to have an important role in preventing pathogen adhesion to host cells (26). Therefore, although it is well-established that SC is crucial for normal bodily functions, the influence of hyperoxia on SC remains clear.

In the present study, investigations into intestinal injuries induced by ROS under hyperoxic conditions were performed. The influence of ROS on the SC in the intestinal epithelium and whether ROS was a predominant factor in causing intestinal injury during hyperoxia were also explored.

\section{Materials and methods}

Cell culture. A human colon adenocarcinoma cell line, Caco-2, was obtained from the Cell Biological Institute of Shanghai, Chinese Academy of Sciences (Shanghai, China). Cells were cultured at $37^{\circ} \mathrm{C}$ in an atmosphere containing 95\% air and $5 \% \mathrm{CO}_{2}$ in high glucose Dulbecco's modified Eagle medium (DMEM; Sigma-Aldrich; Merck KGaA, Darmstadt, Germany) supplemented with $10 \%$ fetal bovine serum (Beijing Dingguo Changsheng Biotechnology Co., Ltd., Beijing, China), $1 \%$ L-glutamine, $100 \mathrm{U} / \mathrm{ml}$ penicillin, $100 \mathrm{mg} / \mathrm{ml}$ streptomycin and $0.25 \mathrm{mg} / \mathrm{ml}$ amphotericin. Culture medium was changed every 2 to 3 days. Prior to treatment, the cells $\left(1 \times 10^{6}\right.$ cells $\left./ \mathrm{ml}\right)$ were plated with fresh DMEM and cultured for 2 days. The cells were then treated with different concentrations of $\mathrm{H}_{2} \mathrm{O}_{2}(100,200$ or $400 \mu \mathrm{M})$, or exposed to $85 \% \mathrm{O}_{2}$ (hyperoxia) at $37^{\circ} \mathrm{C}$ for $24 \mathrm{~h}$. Control cells did not receive treatment. Subsequently, the cultured cells were harvested for RNA and protein extraction. All experiments were repeated 6-10 times.

Annexin V(AV)/propidium iodide (PI) double staining assay. Apoptotic cells were quantified using an AV-fluorescein isothiocyanate (FITC)/PI kit (Nanjing Kaiji Materials Co., Ltd., Nanjing, China) according to the manufacturer's instructions, detected using a flowcytometer (FACSCalibur; BD Biosciences, San Jose, CA, USA) and analyzed with CellQuest Pro software (BD Biosciences, San Jose, CA, USA). Caco-2 cells were plated at the same cell density $\left(1 \times 10^{6} \mathrm{cells} / \mathrm{ml}\right)$ at each passage. Untreated cells were used as the control group. Caco-2 cells were pretreated with either 100,200 or $400 \mu \mathrm{M}$ $\mathrm{H}_{2} \mathrm{O}_{2}$ or $85 \% \mathrm{O}_{2}$ (hyperoxia) for 6,12 , and $24 \mathrm{~h}$. Cells were harvested and resuspended in binding buffer $(\mathrm{pH} 7.5,10 \mathrm{mM}$ HEPES, $2.5 \mathrm{mM} \mathrm{CaCl}_{2}$ and $140 \mathrm{mM} \mathrm{NaCl}$ ) and incubated with AV-FITC and PI at room temperature for $10 \mathrm{~min}$ in the dark prior to flow cytometric analysis. AV-positive cells were considered to be in the early stages of apoptosis, whereas AV and PI double-positive cells were considered to be in the late stages of apoptosis (27). Apoptotic cells were stained with FITC/PI and detected by flow cytometry. The positive area of PI indicated necrotic cells, the positive area of AV and double positive area indicated apoptosis cells. The apoptotic rate of cells was evaluated as follows: Percentage of apoptotic cells $=$ number of apoptotic cells / (number of apoptotic cells + number of viable cells) x 100\%. The mortality rate of cells was evaluated as follows: Percentage of necrotic cells $=$ number of necrotic cells / (number of necrotic cells + number of viable cells) x $100 \%$.

Immunohistochemistry analysis. Caco-2 cells that had received treatment with 100,200 or $400 \mu \mathrm{M} \mathrm{H}_{2} \mathrm{O}_{2}$, or hyperoxia at $37^{\circ} \mathrm{C}$ for $24 \mathrm{~h}$ were cultured on coverslips and fixed with $4 \%$ paraformaldehyde at $37^{\circ} \mathrm{C}$ for $30 \mathrm{~min}$. Fixed cells were subsequently treated with $10 \%$ goat serum at $37^{\circ} \mathrm{C}$ for $30 \mathrm{~min}$, and incubated with mouse anti-human SC (1:1,000; catalogueno. I6635, Sigma-Aldrich; Merck KGaA) at $4^{\circ} \mathrm{C}$ overnight, and was washed with PBS for $5 \mathrm{~min}$ (repeated three times), and incubated with the working solution of secondary antibody (biotin-labeled goat anti-mouse $\mathrm{IgG}$, catalogue no. SP-9002; ZSGB-BIO, Beijing, China) for $40 \mathrm{~min}$ at $37^{\circ} \mathrm{C}$, according to manufacturers instructions. The cells were stained with using a diaminobenzidine kit (1:50; catalogue no. ZLI-9018; ZSGB-BIO, Inc.) at room temperature for 1 min, counterstained with hematoxylin and observed using a digital camera (Olympus Corp., Tokyo, Japan) attached to a light microscope at a magnification of $\mathrm{x} 400$. Primary antibody was replaced with PBS as a negative control. Mean absorbance values for SC protein were determined using Prism Graph version 6.0 software (GraphPad Software, Inc., La Jolla, CA, USA) following scanning.

Western blot analysis. Proteins were extracted from Caco-2 cells according to the manufacturer's instructions as follows: Caco-2 cells were lysed in RIPA buffer (Beyotime Institute of Biotechnology, Shanghai, China), then centrifuged at $14 \mathrm{x} \mathrm{g}$ and $4^{\circ} \mathrm{C}$ for $30 \mathrm{~min}$. Subsequently a BCA Protein Assay Kit (P0013C, Beyotime Institute of Biotechnology) was used to determine the protein concentration according to the manufacturer's instructions. Proteins $(40 \mu \mathrm{g})$ were loaded and separated by $8 \%$ SDS-PAGE (P0012A, Beyotime Institute of Biotechnology) and transferred onto polyvinylidene fluoride membranes. Membranes were incubated with Tris-buffer containing 5\% non-fat milk at room temperature for $2 \mathrm{~h}$ and probed with mouse anti-human SC $(1: 1,000)$ or anti-GAPDH (1:10,000; catalogue no. KC-5G5, Kangchen Bioengineering, Co., Ltd., Shanghai, China) at $4^{\circ} \mathrm{C}$ overnight. The membranes were then washed by a Tris Buffered Saline containing Tween-20 (TBST) at room temperature for $15 \mathrm{~min}$ (repeated three times) and were incubated with a peroxidase-conjugated secondary antibody $(1: 10,000$; catalogue no. ZB-5305; ZSGB-BIO, Inc.) at room temperature for $2 \mathrm{~h}$. Then the membranes were washed by TBST at room temperature for $15 \mathrm{~min}$ (repeated three times). Subsequently, the membranes were incubated with an enhanced chemiluminescent substrate (Thermo Fisher Scientific, Inc., Waltham, MA, USA) and images were captured using a C300 gel imaging system (Azure Biosystems, Inc., Dublin, CA, USA). Tanon 2500 Fully Automatic Digital Gel Imaging system (Tanon Science $\&$ Technology Co., Ltd., Shanghai, China) was used to scan images and analyze densitometry values of SC protein normalized to GAPDH. 
Reverse transcription-quantitative polymerase chain reaction (RT-qPCR) analysis. Total RNA was extracted from Caco-2 cells using TRIzol Reagent (Takara Biotechnology Co., Ltd., Dalian, China) according to the manufacturer's instructions. Total RNA (100 ng) was reverse transcribed into cDNA using a SYBR Premix Ex Taqkit (Takara Biotechnology Co., Ltd.) according to the manufacturer's instructions. Levels of individual RNA transcripts were quantified using qPCR. The following primers were used: SC, forward 5'-GCTTGTCTC CCTGACCCTG-3' and reverse 5'-AATGGCTTTGTTCTC AATCTC-3'; and GAPDH, forward 5'-GCACCGTCAAGG CTGAGAAC-3' and reverse 5'-TGGTGAAGACGCCAG TGGA-3'. Primers and fluorescence probes for SC, and the internal reference (GAPDH), were purchased from Takara Biotechnology Co., Ltd. PCR conditions were as follows: Initial denaturation at $95^{\circ} \mathrm{C}$ for $10 \mathrm{sec}$, followed by 45 cycles of $95^{\circ} \mathrm{C}$ for $5 \mathrm{sec}$ and $60^{\circ} \mathrm{C}$ for $20 \mathrm{sec}$, followed by $1 \mathrm{~min}$ at $60^{\circ} \mathrm{C}$ and $5 \mathrm{sec}$ at $95^{\circ} \mathrm{C}$. The efficiency of amplification for each target gene (GAPDH) was confirmed as $100 \%$ in the exponential phase of PCR. The value of the relative mRNA quantity for the control group was arbitrarily set to one for normalization and the data were analyzed using the comparative Cq method (2- $\left.{ }^{-\Delta \mathrm{Cq}}\right)$ (26). The levels of mRNA in Caco-2 cells exposed to hyperoxia and $\mathrm{H}_{2} \mathrm{O}_{2}$ were compared with that of the control group.

Statistical analysis. Data were expressed as the mean \pm standard deviation (SD). All statistical analyses were performed using SPSS version 20.0 software (IBM Corp., Armonk, NY, USA). A Student's t-test was used to determine significant differences between treatment groups. $\mathrm{P}<0.05$ was considered to indicate a statistically significant difference.

\section{Results}

Cell apoptosis. Cytotoxic effects of $\mathrm{H}_{2} \mathrm{O}_{2}$ are typically attributed to the induction of cell apoptosis (5). The cytotoxicity of $\mathrm{H}_{2} \mathrm{O}_{2}$ on Caco-2 cells was investigated in the present study. Following treatment with $\mathrm{H}_{2} \mathrm{O}_{2}$ for $6 \mathrm{~h}$, the apoptosis rates of cells exposed to 100,200 and $400 \mu \mathrm{M} \mathrm{H}_{2} \mathrm{O}_{2}$ and hyperoxia were significantly increased compared with that of the control group ( $\mathrm{P}<0.05$; Fig. 1). Apoptotic rates were increased in a $\mathrm{H}_{2} \mathrm{O}_{2}$ concentration-dependent manner. In the hyperoxia group, the apoptotic rate was significantly increased compared with those of the $\mathrm{H}_{2} \mathrm{O}_{2}$ groups $(\mathrm{P}<0.05$; Figs. 1 and 2). However, the apoptotic rates of cells exposed to 100,200 and $400 \mu \mathrm{M} \mathrm{H}_{2} \mathrm{O}_{2}$ and hyperoxia for $24 \mathrm{~h}$ were significantly decreased compared with the control group ( $\mathrm{P}<0.05$; Fig. 3).

As indicated in Fig. 4A, the apoptosis rates of cells treated with various concentrations of $\mathrm{H}_{2} \mathrm{O}_{2}$ for $6 \mathrm{~h}$ were significantly increased when compared with those for $24 \mathrm{~h}$ $(\mathrm{P}<0.05)$. Compared with cells treated for $6 \mathrm{~h}$, the apoptotic rates of $\mathrm{H}_{2} \mathrm{O}_{2}$ - and hyperoxia-treated cells for $12 \mathrm{~h}$ were not significantly different. As shown in Fig. 4B, with increasing ROS concentration and duration of incubation, the mortality rates were gradually increased. The mortality rates of the cells treated with $\mathrm{H}_{2} \mathrm{O}_{2}$ and hyperoxia for 12 and $24 \mathrm{~h}$ were significantly increased, as compared with $6 \mathrm{~h}(\mathrm{P}<0.05$; Fig. 4B). These results suggested that increased ROS accelerated cell apoptosis in the early phase of hyperoxia and accelerated cell death in the late phase of hyperoxia (Fig 4B). These findings implied that ROS might be responsible for cell injury during hyperoxia.

Immunohistochemical staining of SC. Immunostaining indicated that SC was mainly localized on the cell membrane and in cytoplasm (Fig. 5A). Compared with the control group, the SC expressions of cells exposed to 100,200 and $400 \mu \mathrm{M}$ $\mathrm{H}_{2} \mathrm{O}_{2}$ were significantly increased. In the hyperoxia group, the morphology of cells was changed, and the expression of SC was significantly increased compared with those of the control and $\mathrm{H}_{2} \mathrm{O}_{2}$ groups $(\mathrm{P}<0.05$; Fig. 5B).

Protein expression levels of SC. Expression levels of SC protein (85 kDa; Fig. 6A) increased in a $\mathrm{H}_{2} \mathrm{O}_{2}$ concentration-dependent manner. Notably, the expression levels of SC were markedly increased in hyperoxia-treated cells, as compared with the control (Fig. 6A). Densitometry analysis revealed that SC levels in hyperoxia-treated cells were significantly increased compared with those in the control $(\mathrm{P}<0.05)$ and $\mathrm{H}_{2} \mathrm{O}_{2}$-treated cells $(\mathrm{P}<0.05$; Fig. 6B).

SC mRNA expression levels. Compared with the control group, the expression levels of SC mRNA were significantly increased in the $200 \mu \mathrm{M}, 400 \mu \mathrm{M} \mathrm{H}_{2} \mathrm{O}_{2}$ and hyperoxia groups $(\mathrm{P}<0.05$; Fig. 7). The mRNA expression levels of $\mathrm{SC}$ increased in a $\mathrm{H}_{2} \mathrm{O}_{2}$ dose-dependent manner. In hyperoxia-treated cells, SC mRNA expression levels were significantly increased compared with $\mathrm{H}_{2} \mathrm{O}_{2}$-treated cells $(\mathrm{P}<0.05$; Fig. 7).

\section{Discussion}

The intracellular redox state is a key determinant of cell fate (28). Oxidative stress is a specific cellular stress that creates reactive species, including free oxygen radicals (4). ROS are generated in the mitochondria (29) and have a critical role in determining the responsiveness of the cell to stress (30). ROS are important in facilitating signal transduction processes within the cell (31) and are able to control cellular growth and death (5). Maintaining balanced intracellular ROS levels is a key factor in preventing pathophysiological conditions (32). ROS, as an important group of free radicals, exerts notable oxidative and biological effects (33). During normal metabolism, ROS signals cells to stimulate proliferation or to induce cellular damage, depending on the concentration (34). Excessively generated ROS are typically counteracted by ubiquitously expressed antioxidant proteins (35). ROS are toxic to the cell and are secondary messengers in intracellular signal transduction (30). Excess ROS production disrupts the redox balance and amplifies the inflammatory responses via NF- $\kappa \mathrm{B}(9)$.

$\mathrm{H}_{2} \mathrm{O}_{2}$ is the primary byproduct of oxidative metabolism (36). A small proportion of mitochondrial $\mathrm{H}_{2} \mathrm{O}_{2}$ is produced by intracellular oxidative stress and has been associated with accelerated ageing (5). $\mathrm{H}_{2} \mathrm{O}_{2}$ is produced and released to impair redox homeostasis during oxidative stress (35) and significantly increases the number of free radicals in cells, which results in critical DNA damage (10). As the levels of ROS increase, $\mathrm{H}_{2} \mathrm{O}_{2}$-induced oxidative stress and the rate of 

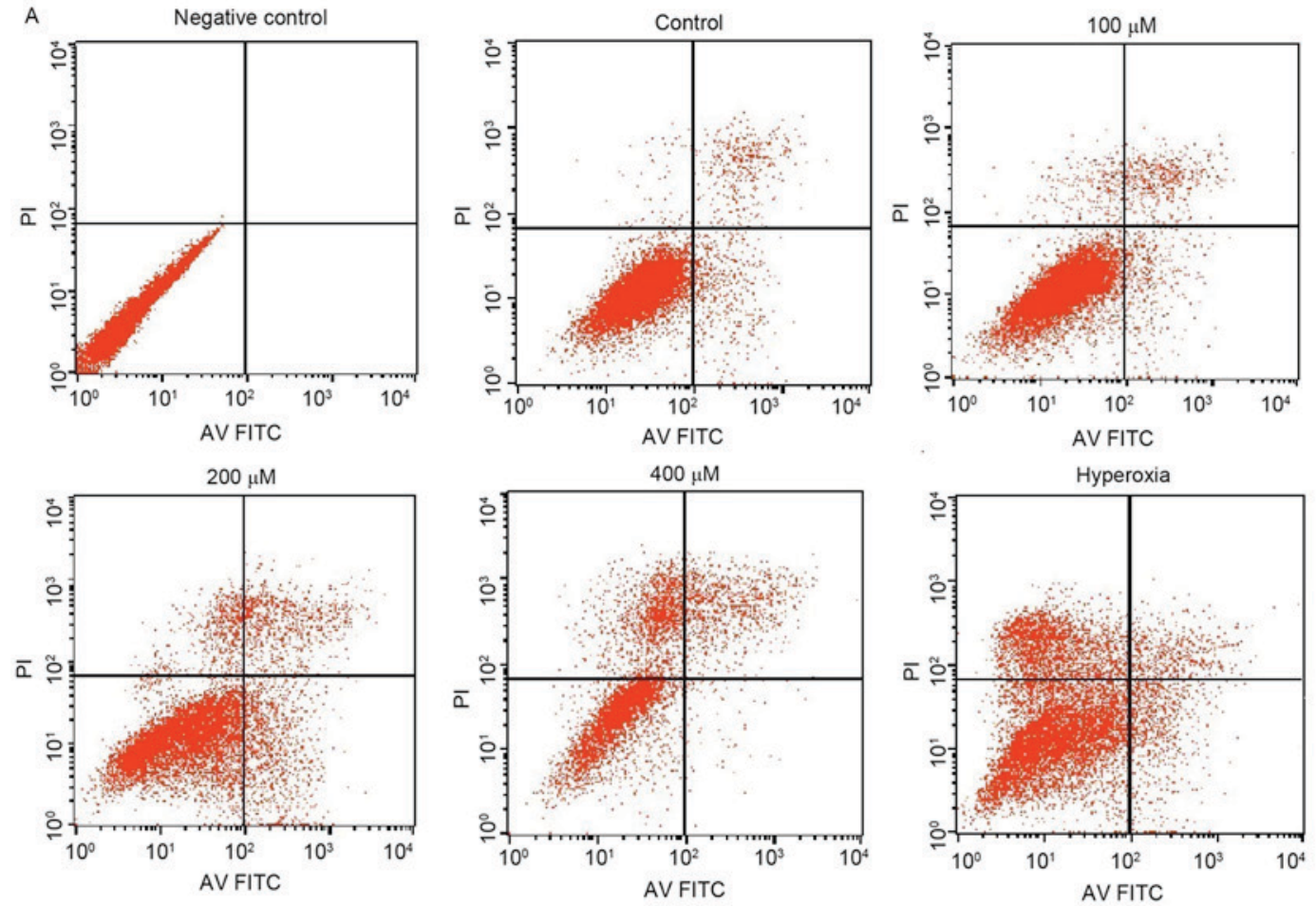

B

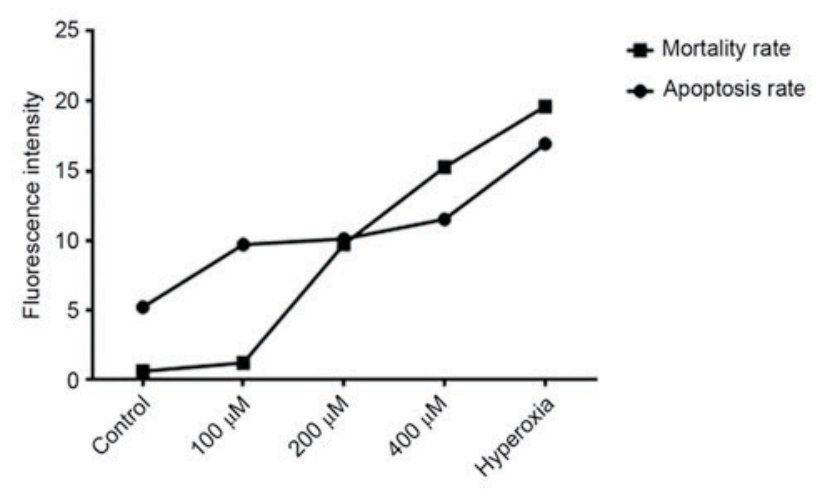

C

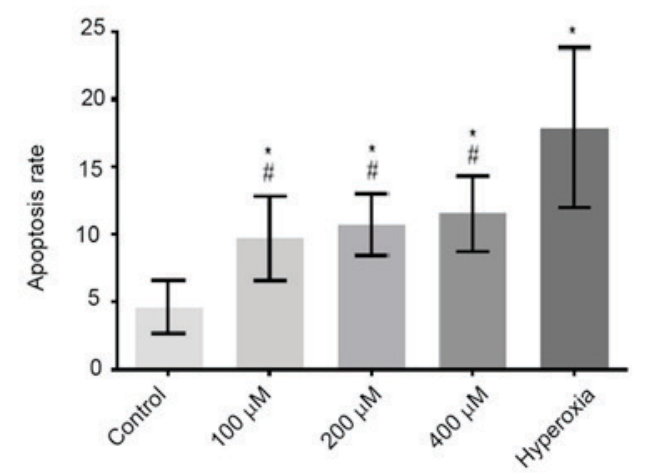

D

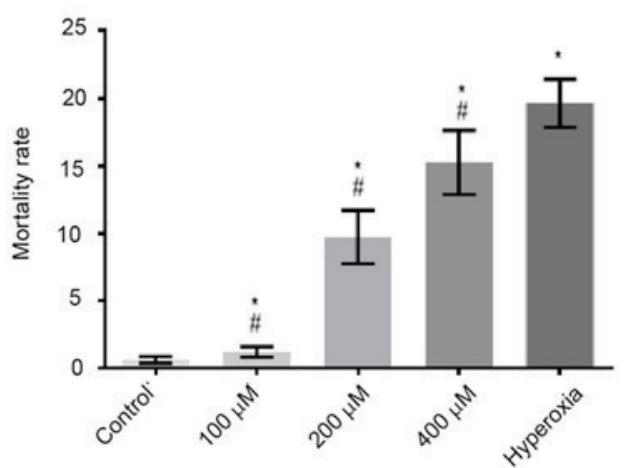

Figure 1. Apoptosis and mortality rates of the cells treated by hyperoxia or hydrogen peroxide $\left(\mathrm{H}_{2} \mathrm{O}_{2}\right)$ for $6 \mathrm{~h}$. (A) Flow cytometry figure, (B) Fluorescence intensity variation, (C) the apoptosis rate and (D) mortality rate variation. Results were presented as mean $\pm \mathrm{SD}$. ${ }^{*} \mathrm{P}<0.05$ vs. the control group; ${ }^{\#} \mathrm{P}<0.05$ vs. the hyperoxia group (unpaired Student's t-test; $\mathrm{n} \geq 6$ ).

apoptosis gradually increases $(37,38)$. Therefore, we hypothesized that an increase in the concentration of $\mathrm{H}_{2} \mathrm{O}_{2}$ affects cell apoptosis.
A previous study reported that ROS was associated with apoptosis of cells (39). In the present study, Caco-2 cells incubated for 6 and $12 \mathrm{~h}$ in the presence of hyperoxia and 

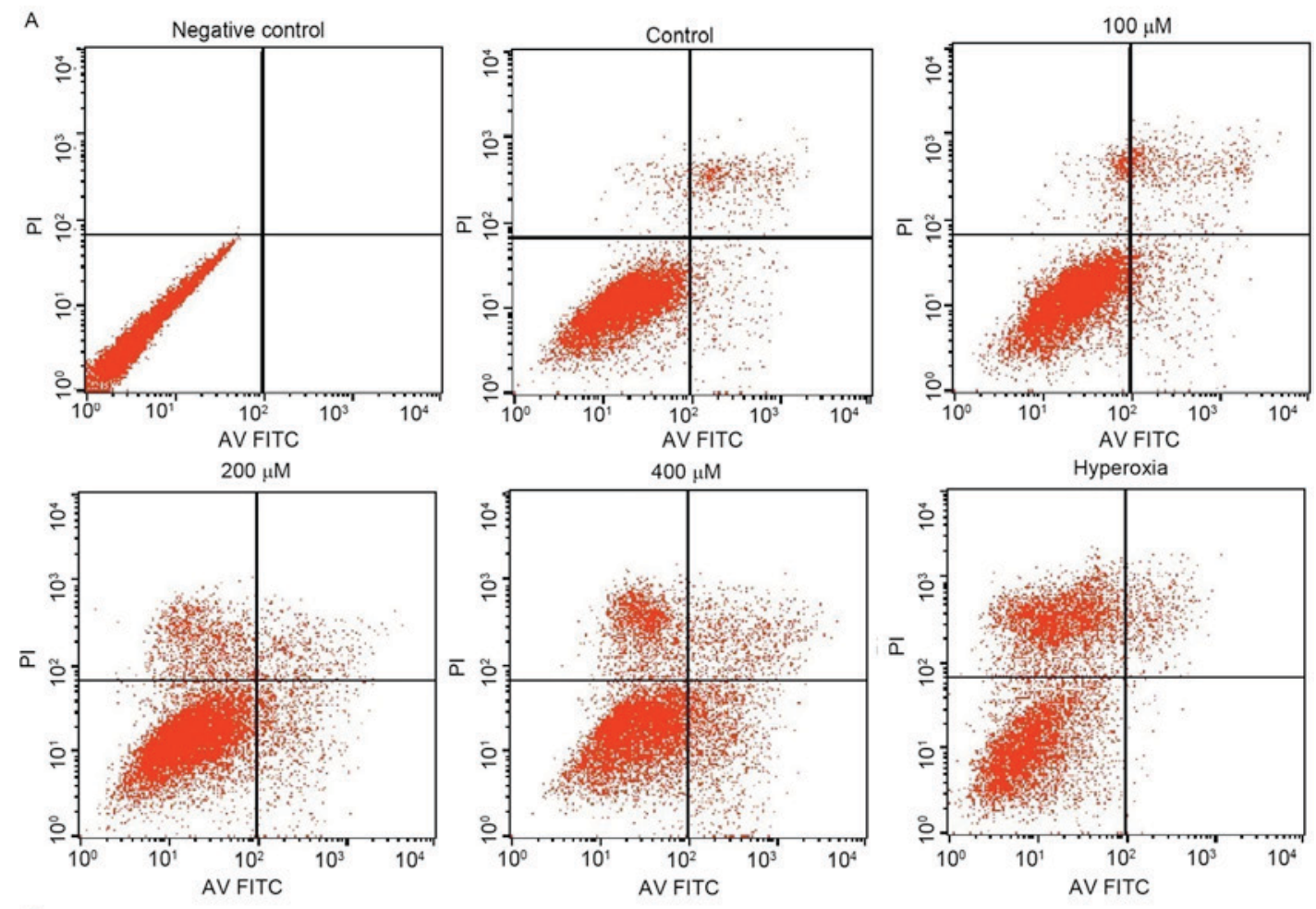

B
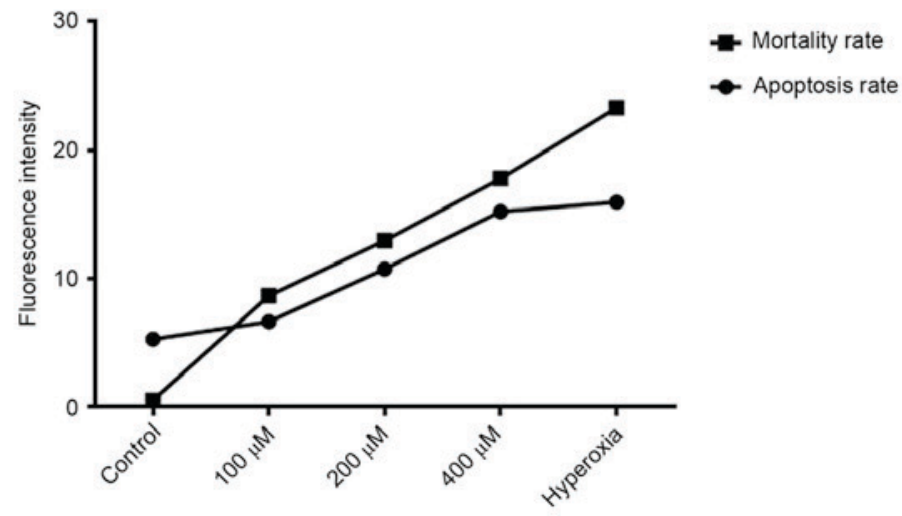

C

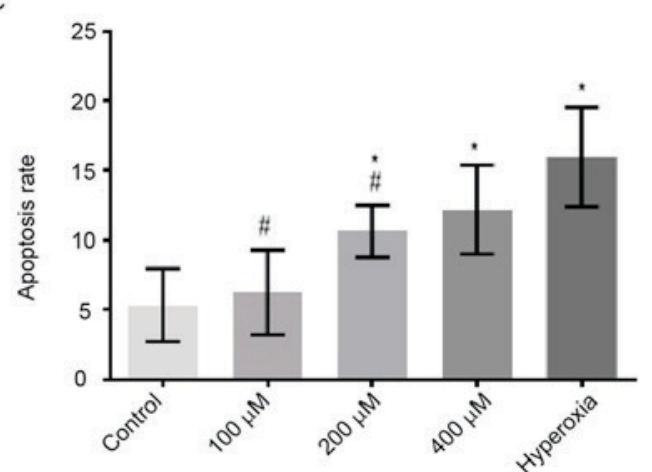

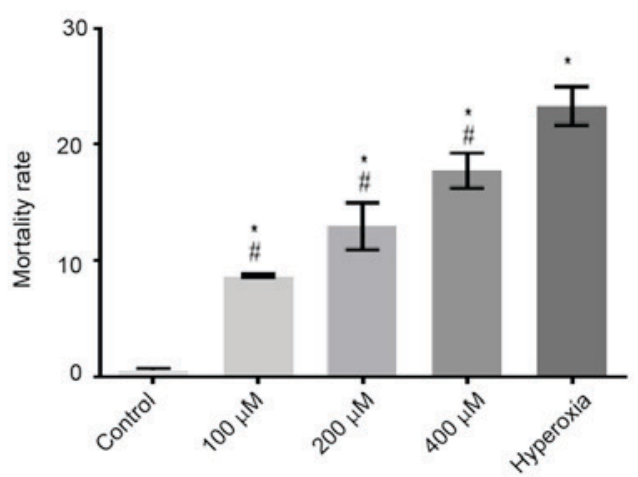

Figure 2. Apoptosis and mortality rates of the cells treated by hyperoxia or $\mathrm{H}_{2} \mathrm{O}_{2}$ for $12 \mathrm{~h}$. (A) Flow cytometry figure, (B) Fluorescence intensity variation, (C) The apoptosis rate and (D) mortality rate variation. Results were presented as mean $\pm \mathrm{SD}$. ${ }^{*} \mathrm{P}<0.05$ vs. the control group; ${ }^{*} \mathrm{P}<0.05$ vs. the hyperoxia group (unpaired Student's t-test; $\mathrm{n} \geq 6$ ).

at higher doses of $\mathrm{H}_{2} \mathrm{O}_{2}$ exhibited a significantly increased number of apoptotic cells. Compared with cells treated for $6 \mathrm{~h}$, apoptosis and mortality rates were significantly increased at $12 \mathrm{~h}$. Furthermore, the mortality rates of cells were significantly increased during hyperoxia and at higher doses of $\mathrm{H}_{2} \mathrm{O}_{2}$ for $24 \mathrm{~h}$, as compared with cells treated for 6 and $12 \mathrm{~h}$. These findings suggested that the large number of ROS produced might result in cell necrosis during prolonged hyperoxia. In addition, increased ROS concentration and longer incubation times resulted in increased apoptotic and 

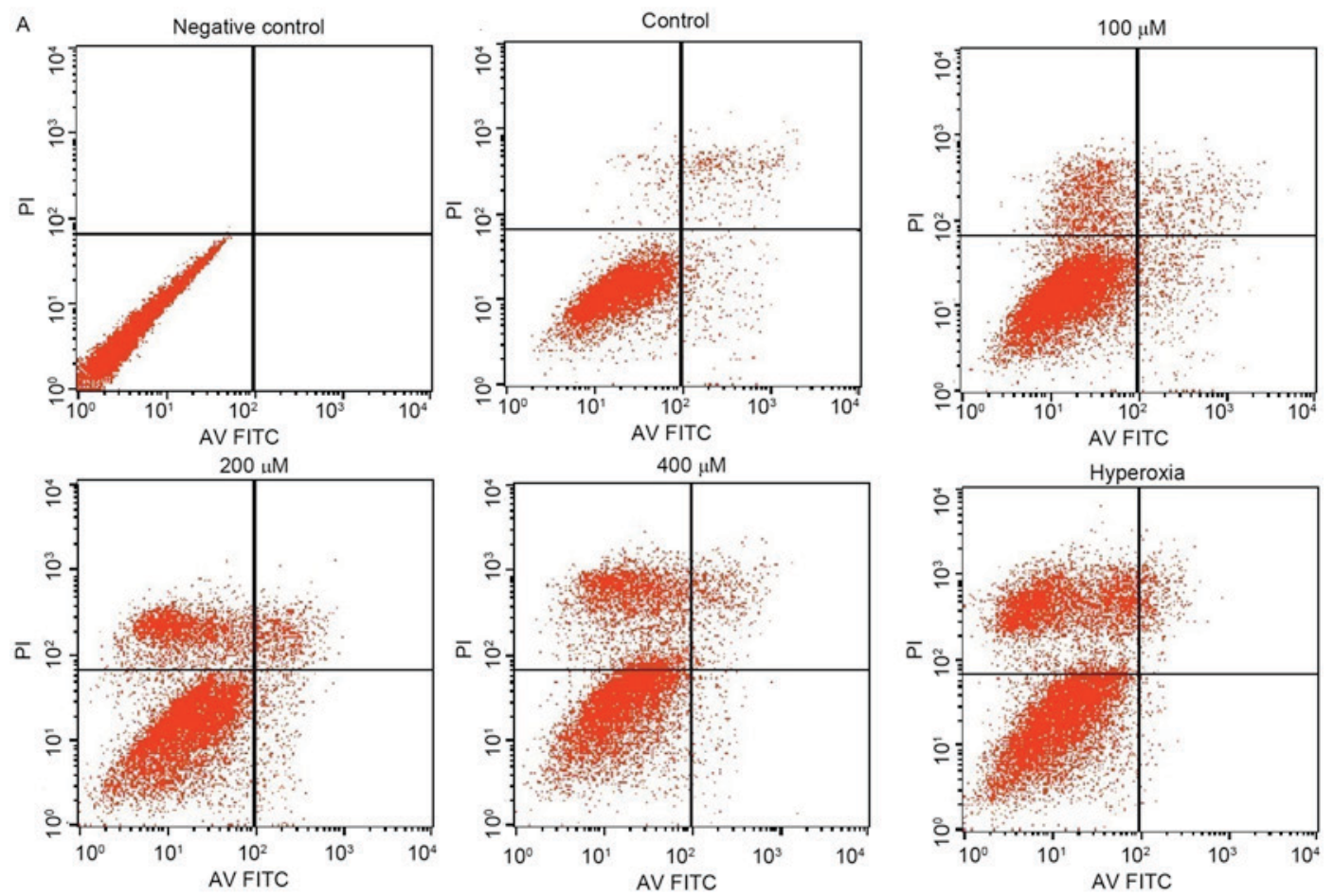

B

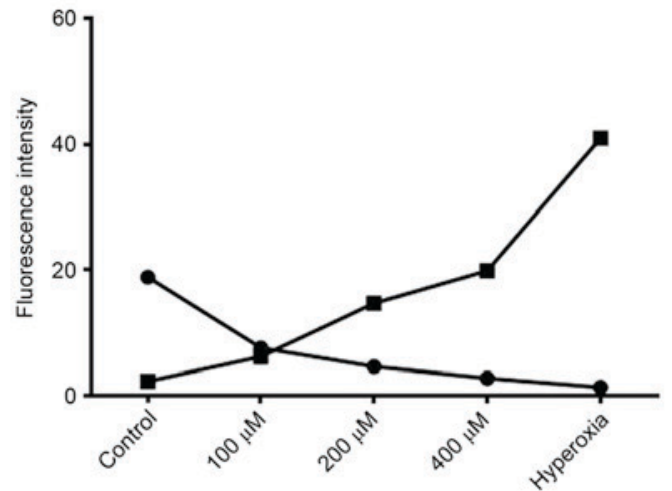

- Mortality rate

- Apoptosis rate

C

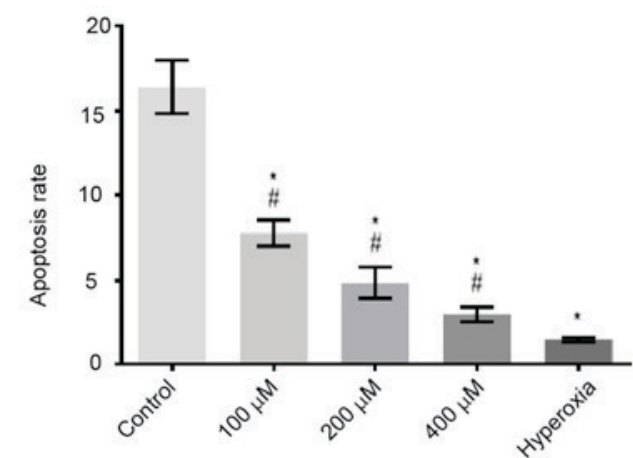

D

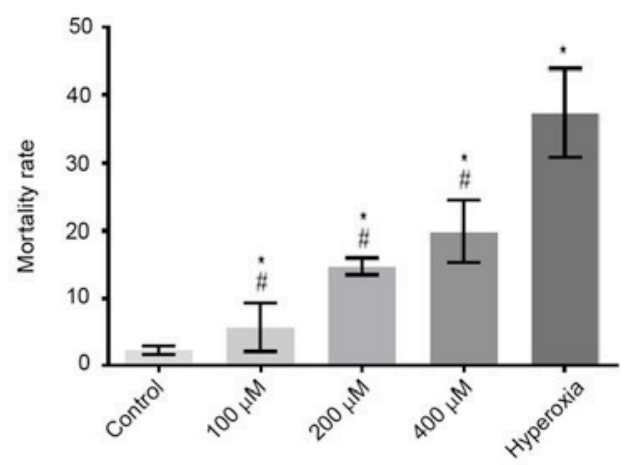

Figure 3. Apoptosis and mortality rates of the cells treated by hyperoxia or $\mathrm{H}_{2} \mathrm{O}_{2}$ for 24 h. (A) Flow cytometry figure, (B) Fluorescence intensity variation, (C) The apoptosis rate and (D) mortality rate variation. Results were presented as mean $\pm \mathrm{SD}$. ${ }^{*} \mathrm{P}<0.05$ vs. the control group; ${ }^{*} \mathrm{P}<0.05$ vs. the hyperoxia group (unpaired Student's t-test; $\mathrm{n} \geq 6$ ).

mortality rates. We therefore concluded that excessive ROS leads to cell mortality.

pIgR is essential in intestinal defense against pathogenic microbes (19). A previous study indicated that upregulation of $\mathrm{pIgR}$ expression increased the capacity of mucosal epithelial cells to transport dimeric IgA (21). Additionally, SIgA, IgA and SC induced by hyperoxia reflect local immunity in the respiratory tract (14). Therefore, the expression of SC protein under hyperoxia conditions or treatment with $\mathrm{H}_{2} \mathrm{O}_{2}$ for $24 \mathrm{~h}$ was determined. Increased oxidative stress 

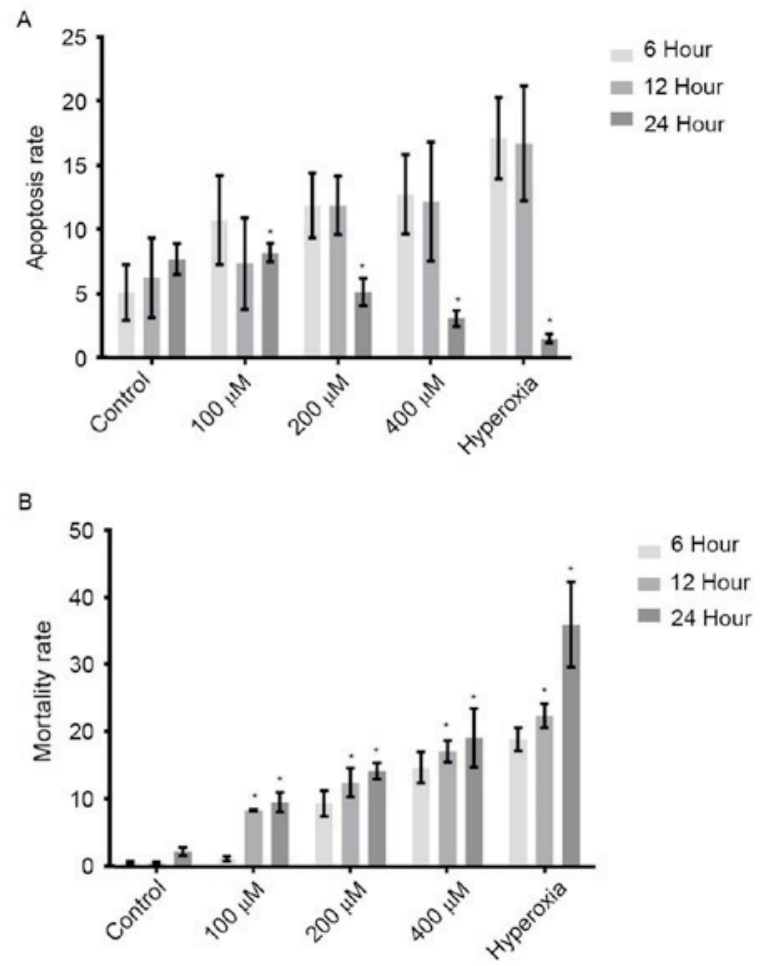

Figure 4. Analysis of apoptosis and mortality rates over time. (A) Apoptosis rates, (B) mortality rates. Results were presented as mean $\pm \mathrm{SD}$. ${ }^{\mathrm{A}} \mathrm{P}<0.05$ vs. the $6 \mathrm{~h}$ group (unpaired Student's t-test; $\mathrm{n} \geq 6$ ).

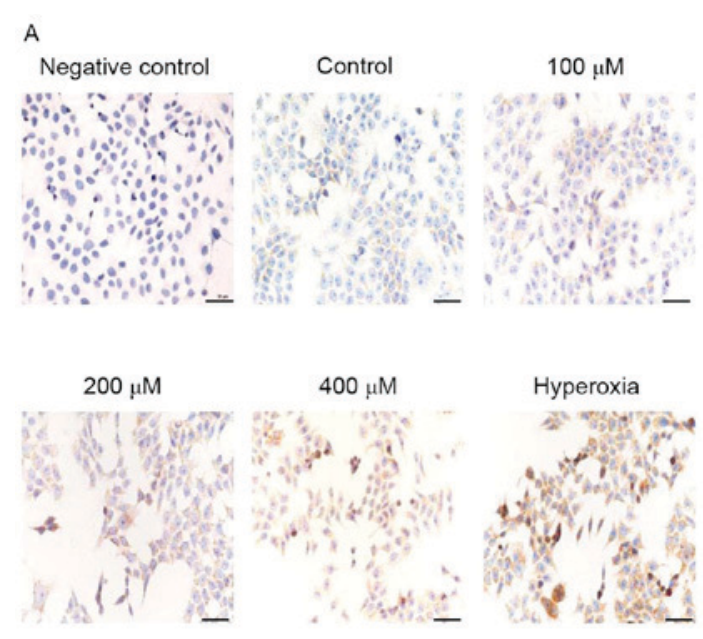

B

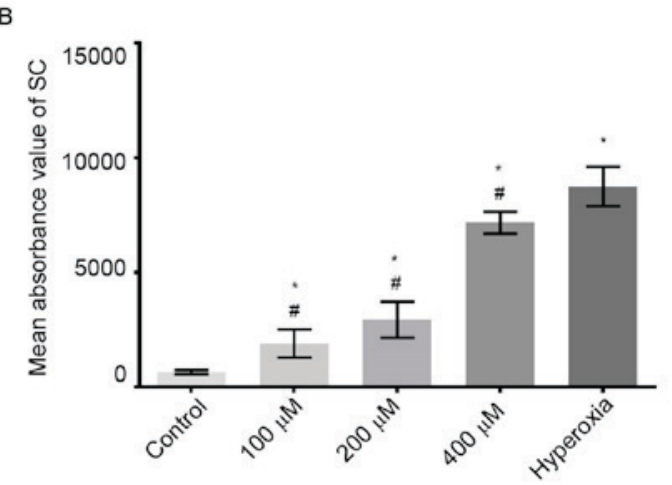

Figure 5. SC immunochemistry staining of the cells treated by hyperoxia or $\mathrm{H}_{2} \mathrm{O}_{2}$. (A) SC staining at a magnification of $\mathrm{x} 400$. Scale bar $50 \mu \mathrm{m}$. (B) The absorbance of SC protein. Results were presented as mean $\pm \mathrm{SD}$. ${ }^{*} \mathrm{P}<0.05$ vs. the control group; ${ }^{~} \mathrm{P}<0.05$ vs. the hyperoxia group (unpaired Student's t-test; $\mathrm{n} \geq 8$ ). SC, secretory component.

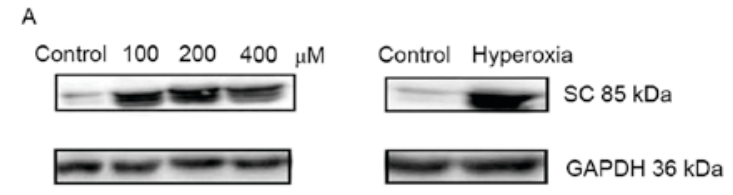

B

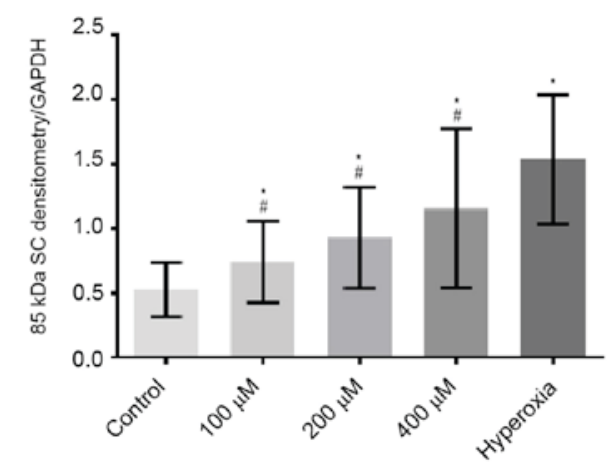

Figure 6. The expression levels of SC protein. (A) The expression levels of SC protein $(85 \mathrm{kDa})$ in hyperoxia and $\mathrm{H}_{2} \mathrm{O}_{2}$ groups. (B) Densitometric analysis. Results were presented as mean $\pm \mathrm{SD}$. ${ }^{*} \mathrm{P}<0.01$ vs. the control group; ${ }^{*} \mathrm{P}<0.05$ vs. the hyperoxia group (unpaired Student's t-test; $n \geq 7$ ). SC, secretory component; GAPDH, glyceraldehyde 3-phosphate dehydrogenase.

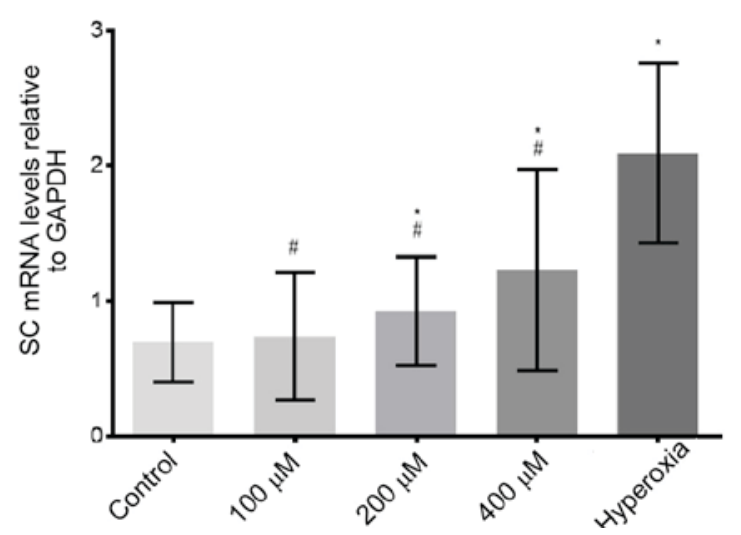

Figure 7. SC mRNA expression levels. Total RNA was extracted from the cells treated with hyperoxia and $\mathrm{H}_{2} \mathrm{O}_{2}$. Then reverse transcription-quantitative polymerase chain reaction was performed. Results were presented as mean $\pm \mathrm{SD}$. ${ }^{*} \mathrm{P}<0.05$ vs. the control group; ${ }^{\#} \mathrm{P}<0.05$ vs. the hyperoxia group (unpaired Student's t-test; $n \geq 9$ ). SC, secretory component; GAPDH, glyceraldehyde 3-phosphate dehydrogenase.

induced by hyperoxia and $\mathrm{H}_{2} \mathrm{O}_{2}$ resulted in a significant increase in mRNA and protein expression levels of SC. Previous studies have indicated that ROS induces cytokines during inflammation (40), and the increased expression of these cytokines may contribute to the expression of $\operatorname{Ig} \mathrm{A}$ and SC (14). The observed increase in SC in the present study suggested that intestinal inflammation might occur in hyperoxia and that ROS might have an important role in such inflammation.

In conclusion, ROS was indicated to cause the injury of intestinal epithelial cells during hyperoxia. Future research on the intestinal mechanisms of ROS-induced injury may demonstrate an even greater role for ROS during intestinal inflammation. However, novel strategies for treating hyperoxia-induced intestinal injury require further investigation. 


\section{Acknowledgements}

The present study was supported by the National Natural Science Foundation of China (grant no. 30871158 and 81170604), the Education Department Foundation of Liaoning Province (grant no. LK201620) and the Outstanding Scientific Fund of Shengjing Hospital (grant no. MA66).

\section{References}

1. Yee M, Buczynski BW and O'Reilly MA: Neonatal hyperoxia stimulates the expansion of alveolar epithelial type II cells. Am J Respir Cell Mol Biol 50: 757-766, 2014.

2. Steer JH, Mann TS, Lo SZ, Inglis JJ, Yap HS, Henry PJ and Joyce DA: Early induction of uncoupling protein-2 in pulmonary macrophages in hyperoxia-associated lung injury. Inhal Toxicol 25: 544-552, 2013.

3. Hong Y, Sun LI, Sun R, Chen H, Yu Y and Xie K: Combination therapy of molecular hydrogen and hyperoxia improves survival rate and organ damage in a zymosan-induced generalized inflammation model. Exp Ther Med 11: 2590-2596, 2016.

4. Roy Chowdhury S, Sengupta S, Biswas S, Sinha TK, Sen R, Basak RK, Adhikari B and Bhattacharyya A: Bacterial fucose-rich polysaccharide stabilizes MAPK-mediated Nrf2/Keap1 signaling by directly scavenging reactive oxygen species during hydrogen peroxide-induced apoptosis of human lung fibroblast cells. PLoS One 9: e113663, 2014.

5. Giorgio M, Trinei M, Migliaccio E and Pelicci PG: Hydrogen peroxide: A metabolic by-product or a common mediator of ageing signals? Nat Rev Mol Cell Biol 8: 722-728, 2007.

6. Carnesecchi S, Deffert C, Pagano A, Garrido-Urbani S, Métrailler-Ruchonnet I, Schäppi M, Donati Y, Matthay MA, Krause KH and Barazzone Argiroffo C: NADPH oxidase-1 plays a crucial role in hyperoxia-induced acute lung injury in mice. Am J Respir Crit Care Med 180: 972-981, 2009.

7. Crane DD, Bauler TJ, Wehrly TD and Bosio CM: Mitochondrial ROS potentiates indirect activation of the AIM2 inflammasome. Front Microbiol 5: 438, 2014

8. Oparka M, Walczak J, Malinska D, van Oppen LM, Szczepanowska J, Koopman WJ and Wieckowski MR: Quantifying ROS levels using CM-H2DCFDA and HyPer. Methods 109: 3-11, 2016.

9. Ishibashi T: Molecular hydrogen: New antioxidant and anti-inflammatory therapy for rheumatoid arthritis and related diseases. Curr Pharm Des 19: 6375-6381, 2013.

10. Cai X, Chen X, Wang X, Xu C, Guo Q, Zhu L, Zhu S and Xu J: Pre-protective effect of lipoic acid on injury induced by $\mathrm{H} 2 \mathrm{O} 2$ in IPEC-J2 cells. Mol Cell Biochem 378: 73-81, 2013.

11. Rhee SG: Cell signaling. $\mathrm{H} 2 \mathrm{O} 2$, a necessary evil for cell signaling. Science 312: 1882-1883, 2006.

12. Li Z, Choo-Wing R, Sun H, Sureshbabu A, Sakurai R, Rehan VK and Bhandari V: A potential role of the JNK pathway in hyperoxia-induced cell death, myofibroblast transdifferentiation and TGF- $\beta 1$-mediated injury in the developing murine lung. BMC Cell Biol 12: 54, 2011.

13. Mikami Y, Iwase T, Komiyama Y, Matsumoto N, Oki H and Komiyama K: Secretory leukocyte protease inhibitor inhibits expression of polymeric immunoglobulin receptor via the NF- $\kappa \mathrm{B}$ signaling pathway. Mol Immunol 67: 568-574, 2015.

14. Liu DY, Jiang T, Wang S and Cao X: Effect of hyperoxia on pulmonary SIgA and its components, IgA and SC. J Clin Immunol 33: 1009-1017, 2013.

15. Macpherson AJ, McCoy KD, Johansen FE and Brandtzaeg P: The immune geography of $\operatorname{IgA}$ induction and function. Mucosal Immunol 1: 11-22, 2008.

16. Mostov KE and Deitcher DL: Polymeric immunoglobulin receptor expressed in MDCK cells transcytoses IgA. Cell 46 . 613-621, 1986.

17. Johansen FE and Kaetzel CS: Regulation of the polymeric immunoglobulin receptor and IgA transport: New advances in environmental factors that stimulate $\mathrm{pIgR}$ expression and its role in mucosal immunity. Mucosal Immunol 4: 598-602, 2011.

18. Bruno ME, Frantz AL, Rogier EW, Johansen FE and Kaetzel CS: Regulation of the polymeric immunoglobulin receptor by the classical and alternative NF- $\kappa$ B pathways in intestinal epithelial cells. Mucosal Immunol 4: 468-478, 2011.
19. Davids BJ, Palm JE, Housley MP, Smith JR, Andersen YS, Martin MG, Hendrickson BA, Johansen FE, Svärd SG, Gillin FD and Eckmann L: Polymeric immunoglobulin receptor in intestinal immune defense against the lumen-dwelling protozoan parasite Giardia. J Immunol 177: 6281-6290, 2006.

20. Perrier C, Sprenger N and Corthesy B: Glycans on secretory component participate in innate protection against mucosal pathogens. J Biol Chem 281: 14280-14287, 2006.

21. Kaetzel CS: The polymeric immunoglobulin receptor: Bridging innate and adaptive immune responses at mucosal surfaces. Immunol Rev 206: 83-99, 2005.

22. Baylor AE, Diebel LN, Liberati DM, Dulchavsky SA, Diglio CA and Brown WJ: The effects of varying oxygen conditions and immunoglobulin A on barrier defense to bacterial invasion. Am Surg 69: 231-237, 2003.

23. Diebel LN, Liberati DM, Brown WJ, Dulchavsky SA, Painter TM, Diglio CA and Montgomery PC: Secretory immunoglobulin A blocks hypoxia-augmented bacterial passage across Madin-Darby canine kidney cell monolayers. J Trauma 43: 759-763, 1997.

24. Torbati D, Tan GH, Smith S, Frazier KS, Gelvez J, Fakioglu H and Totapally BR: Multiple-organ effect of normobaric hyperoxia in neonatal rats. J Crit Care 21: 85-94, 2006.

25. Liu DY and Li JJ: Effect of hyperoxia on the intestinal IgA secretory component in neonatal rats and on intestinal epithelial cells in vitro. Braz J Med Biol Res 43: 1034-1041, 2010.

26. Corthesy B: Role of secretory immunoglobulin A and secretory component in the protection of mucosal surfaces. Future Microbiol 5: 817-829, 2010.

27. Livak KJ and Schmittgen TD: Analysis of relative gene expression data using real-time quantitative PCR and the 2(Delta Delta C(T)) method. Methods 25: 402-408, 2001.

28. Liu B, Tan X, Liang J, Wu S, Liu J, Zhang Q and Zhu R: A reduction in reactive oxygen species contributes to dihydromyricetin-induced apoptosis in human hepatocellular carcinoma cells. Sci Rep 4: 7041, 2014.

29. Thannickal VJ and Fanburg BL: Reactive oxygen species in cell signaling. Am J Physiol Lung Cell Mol Physiol 279: L1005-L1028, 2000.

30. Matsuzawa A and Ichijo H: Redox control of cell fate by MAP kinase: Physiological roles of ASK1-MAP kinase pathway in stress signaling. Biochim Biophys Acta 1780: 1325-1336, 2008.

31. Woolley JF, Stanicka J and Cotter TG: Recent advances in reactive oxygen species measurement in biological systems. Trends Biochem Sci 38: 556-565, 2013.

32. Kang KA, Lee HC, Lee JJ, Hong MN, Park MJ, Lee YS, Choi HD, Kim N, Ko YG and Lee JS: Effects of combined radiofrequency radiation exposure on levels of reactive oxygen species in neuronal cells. J Radiat Res 55: 265-276, 2014.

33. Shen HM and Liu ZG: JNK signaling pathway is a key modulator in cell death mediated by reactive oxygen and nitrogen species. Free Radical Biol Med 40: 928-939, 2006.

34. Kajino-Sakamoto R, Omori E, Nighot PK, Blikslager AT, Matsumoto K and Ninomiya-Tsuji J: TGF-beta-activated kinase 1 signaling maintains intestinal integrity by preventing accumulation of reactive oxygen species in the intestinal epithelium. J Immunol 185: 4729-4737, 2010.

35. Fujisawa T, Takeda $\mathrm{K}$ and Ichijo $\mathrm{H}$ : ASK family proteins in stress response and disease. Mol Biotechnol 37: 13-18, 2007.

36. Xiao J, Deng J, Lv L, Kang Q, Ma P, Yan F, Song X, Gao B, Zhang $\mathrm{Y}$ and $\mathrm{Xu}$ J: Hydrogen peroxide induce human cytomegalovirus replication through the activation of p38-MAPK signaling pathway. Viruses 7: 2816-2833, 2015.

37. Ma Z, Moruzzi N, Catrina SB, Grill V and Björklund A: Hyperoxia inhibits glucose-induced insulin secretion and mitochondrial metabolism in rat pancreatic islets. Biochem Biophys Res Commun 443: 223-228, 2014.

38. Jin S, Ray RM and Johnson LR: TNF-alpha/cycloheximide-induced apoptosis in intestinal epithelial cells requires Rac1-regulated reactive oxygen species. Am J Physiol Gastrointest Liver Physiol 294: G928-G937, 2008.

39. Lee MK, Lu Y, Di LQ and Xu HQ: Protection of Tong-Sai-Mai Decoction against Apoptosis Induced by $\mathrm{H} 2 \mathrm{O} 2$ in PC12 Cells: Mechanisms via Bcl-2-Mitochondria-ROS-INOS Pathway. Evid Based Complement Alternat Med 2014: 371419, 2014.

40. Kina S, Nakasone T, Takemoto H, Matayoshi A, Makishi S, Sunagawa N, Liang F, Phonaphonh T and Sunakawa H: Regulation of chemokine production via oxidative pathway in HeLa cells. Mediators Inflamm 2009: 183760, 2009. 